\title{
Jurist-Diction
}

Volume 2 No. 6, November 2019

Histori artikel: Submit 2 September 2019; Diterima 2 Oktober 2019; Diterbitkan online 1 November 2019.

\section{Kekerasan Seksual dalam Hukum Internasional}

\author{
Mella Fitriyatul Hilmi \\ mellahilmi@gmail.com \\ Universitas Airlangga
}

\begin{abstract}
Violence against women and children as vulnerable can occur in all situations, that is when conflict takes place, the process of escape, and in refugee camps. The International Rescue Committee conducted a survey in 2015 which showed that $40 \%$ of 190 women and girls in Dara'a and Quneitra had experienced sexual violence from personnel of International Organizations when accessing humanitarian assistance services. Sexual violence that occurs in Syria is an act of sexual violence with abuse of power, or abuse of trust, for the purpose of sexual satisfaction, as well as to gain profits in the form of money, social, political and etc. Based on Article 7 Paragraph (1) Rome's Statute of The International Criminal Court, sexual violence is a crime against humanity which is included in the category of the Most Serious Crime, so The International Law has a role in this matter. This research is a normative juridical study, which discusses the principles and concepts of International Law concerning the position of International Organizations as Subjects of International Law which have Legal Personality and Legal Capacity. Therefore it is necessary to know the arrangements related to sexual violence in international law.
\end{abstract}

Keywords: Sexual Violence; Definition; The Most Serious Crime.

\begin{abstract}
Abstrak
Kekerasan terhadap perempuan dan anak sebagai kaum rentan dapat terjadi dalam segala situasi yakni saat konflik berlangsung, proses melarikan diri, maupun di tenda pengungsian. The International Rescue Committee melakukan survei pada tahun 2015 yang menunjukkan bahwa 40\% dari 190 perempuan dan anak perempuan di Dara'a dan Quneitra telah mengalami kekerasan seksual dari para personil Organisasi Internasional saat mengakses layanan bantuan kemanusiaan. Kekerasan seksual yang terjadi di Suriah adalah tindak kekerasan seksual dengan penyalahgunaan kekuasaan, atau penyalahgunaan kepercayaan, untuk tujuan kepuasan seksual, maupun untuk memperoleh keuntungan dalam bentuk uang, sosial, politik dan lain sebagainya. Berdasarkan Pasal 7 Ayat (1) Rome Statute of The International Criminal Court, kekerasan seksual adalah tindak kejahatan terhadap kemanusiaan (crimes against humanity) yang masuk dalam kategori The most Serious Crime, sehingga Hukum Internasional punya peran dalam hal ini. Penelitian ini merupakan penelitian yuridis normatif, dimana membahas terkait asas dan konsep Hukum Internasional mengenai kedudukan Organisasi Internasional selaku Subjek Hukum Internasional yang memiliki Legal Personality dan Legal Capacity. Oleh karena itu perlu diketahui pengaturan terkait dengan kekerasan seksual dalam hukum internasional
\end{abstract}

Kata Kunci: Kekerasan Seksual; Definisi; The Most Serious Crime.

\section{Pendahuluan}

Kekerasan terhadap perempuan dan anak dapat terjadi baik dalam kondisi konflik maupun kondisi damai. Dalam kondisi tersebut sangat dimungkinkan munculnya krisis kemanusiaan. Krisis kemanusiaan yang dialami diantaranya kesulitan mendapatkan air bersih, makanan, tempat berteduh, kesehatan, pendidikan, 
dan kebutuhan dasar lainnya. ${ }^{1}$ Kondisi inilah yang membuat perempuan dan anak sangat rentan terhadap tindak kekerasan. Menurut United Nations Women diperkirakan terdapat 35\% perempuan di dunia telah mengalami kekerasan fisik maupun kekerasan seksual di satu titik dalam hidupnya. ${ }^{2}$ Permasalahan yang sama terjadi pada anak yakni berdasarkan laporan berjudul "Ending Violence in Childhood: Global Report 2017, kekerasan pada anak terjadi hampir universal yakni selama setahun sebanyak 1,7 milyar anak di dunia mengalami kekerasan. Kekerasan tersebut diantarnya bullying, perkelahian, kekerasan seksual, hukuman fisik di rumah dan sekolah. ${ }^{3}$

Kekerasan seksual terhadap perempuan dan anak dapat terjadi dalam segala situasi, yakni bukan saja saat konflik berlangsung namun juga pada saat proses melarikan diri dari konflik, maupun di tenda pengungsian. Hal tersebut adalah dimana struktur sosial sedang mengalami disintegrasi. ${ }^{4}$ Kondisi ini terjadi di Suriah, masyarakat dipaksa untuk melarikan diri dari rumah untuk berlindung baik di dalam maupun ke luar negeri yakni negara tetangga seperti Turki dan Lebanon sebagaimana berdasarkan data dari United Nations High Commissioner for Refugees atau yang selanjutnya akan disebut UNHCR pada bulan Februari $2017 .{ }^{5}$

Perang saudara Suriah adalah sebuah konflik bersenjata berbagai pihak dengan intervensi internasional yang berlangsung di Suriah. ${ }^{6}$ Permasalahan muncul sejak adanya protes kebangkitan dunia Arab di tahun 2011, dan meningkat ke arah

\footnotetext{
1 Abuja, 'Nigeria : Boko Haram Attacks Cause Humanitarian Crisis' (Human Rights Watch, 2014) <http://www.hrw.org/news/2014/03/14/nigeria-boko-haram-attacks-cause-humanitarian-crisis $>$, accessed 22 November 2018.

2 Adinda Ayu Shabrina, 'Peran United Nations High Commissioner for Refugee (UNHCR) dalam Menangani Pengungsi Suriah Korban Sexual and Gender - based Violence (SGBV) di Lebanon' (2018) 4 Journal of International Relations.[49].

3 Bernat Armangue, '75 \% Anak di Dunia Jadi Korban Kekerasan' (VOA, 2017) < https:// www.voaindonesia.com/a/tujuh-puluh-lima-persen-anak-di-dunia-jadi-korban-kekerasan/4047830. html >, accessed 28 September 2018.

4 Adinda Ayu Shabrina, Op. Cit.[81].

5 ibid.

6 Laila Bassam, 'Iran troops to join organisasi internasional Syria war, Russia bombs group trained by CIA', (World News, 2015) < http://www.reuters.com/article/us-mideast-cri$\underline{\text { sis-russia-syria/iran-trooPasal-to-join-syria-war-russia-bombs-group-trained-by-cia-idUSKCN0R- }}$

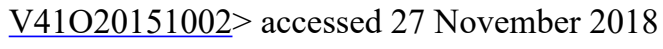


konflik bersenjata setelah terjadi kekerasan atas protes untuk menekan Pemerintah Presiden Bashar al-Assad mundur dari jabatannya. Perang tersebut melibatkan Pemerintah Suriah, kelompok aliansi longgar pemberontak Arab Suriah, Pasukan Demokratik Suriah, kelompok jihaidst Salafi (termasuk Front al-Nusra), serta Irak dan Syam. ${ }^{7}$ Semua pihak menerima dukungan besar dari aktor asing, dan banyak yang mengarahkan untuk melabelinya sebagai perang proksi yang dilancarkan oleh negara-negara besar regional di dunia. ${ }^{8}$ Berdasarkan hasil penelitian The Syrian Center for Policy and Research konflik di Suriah telah menewaskan lebih dari 470.000 orang. Masyarakat sipil dibawa ke pengungsian di beberapa daerah diantaranya bagian selatan Suriah saat konflik terjadi.

Beberapa tahun terakhirpun diketahui telah terjadi kekerasan seksual terhadap perempuan dan anak. The International Rescue Committee di bulan Juni 2015 melakukan survei terhadap 190 perempuan dan anak perempuan di Dara'a dan Quneitra, hasil yang ditemukan bahwa $40 \%$ dari mereka telah mengalami kekerasan seksual saat mengakses layanan bantuan kemanusiaan. Survei dilakukan setelah ditemukannya laporan oleh penasihat kemanusiaan yang membentuk kelompok diskusi di tenda pengungsian bagian selatan Suriah. Para perempuan disana menceritakan bahwa mereka mendapat perlakuan tersebut dari para penyalur bantuan kemanusiaan dan petugas pemerintah kota di daerahnya. ${ }^{9}$

Para pemberi bantuan kemanusiaan tersebut diantaranya ialah organisasi publik internasional di bawah Perserikatan Bangsa-Bangsa atau yang selanjutnya akan disebut (PBB) yang salah satunya adalah The United Nations Children's Fund atau yang selanjutnya akan disebut UNICEF dan juga organisasi internasional yang bersifat privat yakni The Oxford Committee for Famine Relief atau yang sering disebut dengan Oxfam International. UNHCR sebenarnya telah mengetahui adanya tuduhan kekerasan

\footnotetext{
7 Sevirna Ratri Aryani, 'Astana Process sebagai Mekanisme Penyelesaian Konflik di Suriah’, Skripsi Fakultas Hukum Universitas Airlangga, (2018).[2].

8 Fawaz Gerges, 'Saudi Arabia and Iran must end their proxy in Syria', (The Guardian. com, 2013) < http://www.theguardian.com/commentisfree/2013/dec/15/saudia-arabia-iran-proxywar-syria $>$, accessed 27 November 2018.

9 Konflik Suriah : BBC News, Op.Cit
} 
seksual di bagian selatan Suriah tersebut, namun tidak adanya informasi dan data yang cukup membuat tidak dapat pula dilakukannya identifikasi dan pengambilan tindakan terhadap individu maupun organisasi internasional yang terlibat.

Kondisi di atas menunjukkan adanya pengabaian tindak kekerasan seksual terhadap perempuan dan anak baik oleh pemerintah Suriah maupun masyarakat internasional, walaupun hal ini terjadi agar bantuan kemanusiaan dapat tersalurkan. Suriah merupakan parties dari Convention on the Elimination of All Form of Discriminations Againts Women atau yang selanjutnya akan disebut CEDAW sejak 28 Maret 2003. Secara pengaturan dalam hukum internasional, CEDAW adalah Konvensi internasional yang bergerak di bidang hak asasi perempuan ini mewajibkan anggotanya untuk mengimplementasikan amanat dari konvensi tersebut mengenai pemenuhan hak asasi perempuan. Negara diwajibkan untuk tidak hanya menerapkan ketentuan yang ada di dalam CEDAW, namun juga harus dapat menerapkan sanksi kriminalitas terhadap pelaku tindak kekerasan seksual terhadap wanita. ${ }^{10}$ Pembentukan pengadilan $A d H o c$ di sebuah negara dapat dilakukan dalam rangka menyelesaikan kasus kekerasan seksual yang ada sebagaimana yang terjadi di Suriah. Namun dalam rangka negara tersebut tidak mampu menyelesaikannya maka di sinilah peran masyarakat internasional untuk menyelesaikan melalui Pengadilan Pidana Internasional atau yang disebut dengan International of Criminal Court atau yang selanjutnya akan disebut (ICC).

Selanjutnya secara spesifik seperti apa pengaturan kekerasan seksual dalam hukum internasional ? Diketahui dalam Pasal 7 Statuta Roma menyatakan bahwa kekerasan seksual dalam perang merupakan tindakan crimes against humanity. Kekerasan seksual merupakan suatu kejahatan kemanusiaan dan kejahatan perang yang dapat mengancam hidup manusia. ${ }^{11}$ Berdasarkan Pasal 1 Statuta Roma bahwa ICC memiliki jurisdiksinya

${ }^{10}$ Ridhana Swastika Chresna, 'Implementasi Convention on The Elimination of All Forms Discrimination Against Women (CEDAW) terhadap Kasus Kekerasan Seksual di Wilayah Shan Myanmar pada 1996-2001', Skripsi Fakultas Ilmu Sosial dan Ilmu Politik Universitas Airlangga, (2012).[15].

${ }^{11}$ Crime Burma, 'Analysis of Sexual Violence', (International Human Rights in Clinic Harvard Law School, 2009) < http://www.law.harvard.edu/programs/hrp/documents/Crimes-in-Burma. pdf $>$ accessed 27 November 2018 
atas kejahatan paling serius yang menjadi perhatian internasional dan kejahatan yang tertulis dalam statute ini. Dan Pasal 25 Statuta Roma juga mengatakan bahwa ICC memiliki yursidiksi natural persons. Sehingga pelaku tindakan kekerasan seksual dapat dimintai pertanggungjawabannya secara hukum internasional.

Hukum internasional mengenal adanya International Criminal Court (ICC) dan International Court of Justice (ICJ). ICC merupakan lembaga pengadilan internasional guna mengadili pelaku the mosts serious crimes concern to international community as whole secara individual. This permanent institution, established by international treaty, will complement national jurisdictions that are unable or unwilling to bring justice the prepetrators of genocide, war crimes and crimes againt humanitiy. Lembaga ini dapat melengkapi yurisdiksi nasional yang tidak dapat menyelesaikan permasalahannya terkait salah satunya adalah genosida, kejahatan perang dan kejahatan terhadap kemanusiaan. ${ }^{12}$ Maka tulisan ini akan menganalisis mengenai pengaturan Hukum Internasional terhadap kekerasan seksual melalui tulisan yang berjudul "Pengaturan Kekerasan Seksual dalam Hukum Internasional".

\section{Metode Penelitian}

Dalam penelitian ini penulis menggunakan tipe penulisan Doctrinal research. ${ }^{13}$ Pengertian Doctrinal research adalah suatu penelitian yang menghasilkan penjelasan yang sistematis mengenai norma-norma hukum yang mengatur suatu kategori hukum tertentu dalam hal ini mengenai hukum pajak dan kepailitan, menganalisis hubungan antar norma hukum, menjelaskan bidang-bidang yang sulit, dan diharapkan juga memberikan prediksi mengenai perkembangan norma hukum di masa depan.

\section{Definisi Kekerasan Seksual}

Kekerasan seksual pada dasarnya mulai dikenal oleh masyarakat international pasca perang dunia II di tahun 1945. Kondisi tersebut terjadi saat Persidangan Batavia

\footnotetext{
${ }_{12}$ Article 1 Rome Statute of The International Criminal Court, 1974

13 Peter Mahmud Marzuki, Penelitian Hukum (Kencana Prenada Media Group 2008).[32]
} 
diadakan dalam rangka menghukum prajurit-prajurit Jepang atas perlakuannya terhadap perempuan-perempuan Belanda sebagai budak seksual pada tahun 1948. ${ }^{14}$

Perkembangan definisi terkait kekerasan seksual dalam hukum internasional diawali dengan munculnya kasus-kasus pemerkosaan, selanjutnya pengaturan terkait kekerasan seksual yang dilihat dari sejarah munculnya lebih memfokuskan pada kekerasan seksual yang terjadi dalam kondisi konflik bersenjata. Munculnya International Criminal Tribunal of Yugoslavia yang selanjutnya disingkat ICTY pada tahun 1993 terkait kasus pemerkosaan yang dilakukan oleh kombatan pada saat itu memberikan yurisprudensi pertama dalam hukum internasional. ${ }^{15}$

Berdasarkan Pasal 7 Ayat (1) huruf g Rome Statute of The International Criminal Court yang berbunyi :

"For the purpose of this Statute, "crime against humanity" means any of the following acts when committed as part of a widespread or systematic attack directed against any civilian population, with knowledge of the attack : (a) ...; (b) ...; ... (g) Rape, sexual slavery, enforced prostitution, forced pregnancy, enforced sterilization, or any other form of sexual violence of comparable gravity; ...."

Berdasarkan pasal tersebut yang termasuk dalam kekerasan seksual yang diantaranya adalah pemerkosaan, perbudakan seksual, pemaksaan prostitusi, penghamilan paksa, pemaksaan sterilisasi dan kekerasan seksual berat lainnya dikategorikan sebagai kejahatan terhadap kemanusiaan dengan terpenuhinya unsur berdasarkan pasal tersebut.

Berdasarkan Pasal 5 statuta ICTY pemerkosaan didefinisikan sebagai kejahatan terhadap kemanusiaan, maka dalam putusannya hakim mengadilinya sebagai pelanggaran berat atau pelanggaran hukum dan kebiasaan perang berdasarkan pasal lainnya dalam statuta ICTY. Kemudian di tahun 1994 muncul pula International Criminal Tribunal of Rwanda yang selanjutnya akan disingkat ICTR yang menangani kasus pemerkosaan saat itu. Akan tetapi dalam mengadilinya hakim pada saat itu memberikan definisi yang berbeda dari definisi pemerkosaan sebagaimana pada ICTY.

${ }^{14}$ Atikah Nuraini et al, 'Hukum Pidana Internasional dan Perempuan : Sebuah Resource Book untuk Praktisi', (Komnas Perempuan, 2013).[28].

15 ibid 
Berdasarkan Pasal 3 Statuta ICTR pemerkosaan pun didefinisikan sebagai kejahatan kemanusiaan, namun terjadi perkembangan substantive yang positif meliputi :

a. Definisi pemerkosaan sebagai penyiksaan dan penghukuman pertama untuk kejahatan seksual sebagai genosida dan kejahatan kemanusiaan.

b. Definisi pemerkosaan sebagai pelanggaran hukum dan kebiasaan perang.

c. Mengklarifikasi bahwa tanggungjawab komando dapat menjadi dasar dari suatu penuntutan pemerkosaan.

d. Penuntutan untuk kejahatan seksual dalam konflik internal.

e. Adanya perluas definisi pemerkosaan, dimana perkembangan dalam Akayesu adanya perluasan yang mendefinisikan pemaksaan sebagai tidak adanya kebebasan memutuskan (free will), ditinjau dari konteks situasi pada saat itu.

f. Bahwa "pemerkosaan dan bentuk kekerasan seksual lainnya ... menyebabkan kesakitan fisik maupun mental yang parah".

Pembaharuan definisi perkosaan di atas berdasarkan jurisprudensi ICTR ini tetap menunjukkan batasan dalam penanganan subtantif pengadilan pidana internasional tentang kejahatan terhadap perempuan. Dimana perkosaan sebagai salah satu bentuk kekerasan seksual tetap menjadi suatu elemen dari banyak dakwaan namun tidak sebagai yang utama. ${ }^{16}$

Seiring dengan perkembangan kondisi masyarakat internasional, Majelis Umum PBB menyadari bahwa kekerasan terhadap perempuan yang salah satunya ialah kekerasan seksual merupakan hambatan terhadap pembangunan dan perdamaian dunia, sehingga pada tahun 1993 berdasarkan Pasal 1 Deklarasi Penghapusan kekerasan Terhadap Perempuan Majelis Umum PBB mendefinisikan kekerasan terhadap perempuan sebagai tindakan kekerasan berbasis gender yang menghasilkan atau memungkinkan menghasilkan cedera fisik, seksual, atau psikologis atau penderitaan terhadap perempuan, termasuk ancaman untuk melakukan tindakan-tindakan seperti ini, pemaksaan atau penghilangan kebebasan secara acak, baik terjadi di kehidupan publik atau pribadi. ${ }^{17}$

UNHCR sendiri menggunakan definisi Sexual and Gender-Based Violence

${ }^{16}$ Sanam Naraghi Anderlini, Camille Pampell Conaway dan Lisa Kays, 'Transitional Justice and Reconciliation' (2004).[9].

${ }^{17}$ Declaration on the Elimination of Violence against Women, General Assembly A/ RES/48/104, 1993. 
atau yang disingkat dengan $S G B V$ yang sudah diperluas berdasarkan Majelis Umum PBB Declaration on the Elimination of Violence against Women yaitu tindakan kekerasan yang ditujukan pada seseorang atas dasar gender atau jenis kelamin termasuk diantaranya pemerkosaan, eksploitasi seksual, prostitusi paksa, pernikahan paksa, dan pernikahan anak merupakan jenis-jenis $S G B V .{ }^{18}$ Definisi ini mencakup kekerasan yang terjadi di keluarga, di dalam masyarakat umum, dan kekerasan yang dilakukan atau dibiarkan oleh negara. Bentuk-bentuk kekerasan berbasis gender termasuk tetapi tidak terbatas pada: kekerasan domestik, penganiayaan seksual, perkosaan, pelecehan seksual, perdagangan perempuan, prostitusi paksa, dan tindakan-tindakan yang berbahaya terhadap perempuan.

Sejalan dengan hal tersebut Table of Contents dari UN Women mendefinisikan kekerasan seksual adalah setiap penyalahgunaan yang terjadi pada kondisi kerentanan, yakni rentan kekuasaan atau kepercayaan guna tujuan seksual, termasuk dalam rangka menguntungkan secara finansial, sosial atau politik dari eksploitasi seksual orang lain. ${ }^{19}$ Selanjutnya dalam The World Health Organization dalam Understanding and Addressing Violence Against Women:

"The World Health Organization (WHO) defines sexual violence as: 'Any sexual act, attempt to obtain a sexual act, unwanted sexual comments or advances, or acts to traffic or otherwise directed against a person's sexuality using coercion, by any person regardless of their relationship to the victim, in any setting, including but not limited to home and work. Coercion can encompass: varying degrees of force; psychological intimidation; blackmail; or threats (of physical harm or of not obtaining a job/grade etc)", ${ }^{20}$

World Health Organization mendefinisikan kekerasan seksual sebagai segala bentuk tindakan seksual, yakni upaya untuk mendapatkan tindakan seksual, rayuan atau komentar seksual yang tidak diinginkan, atau tindakan yang mengarah pada seksualitas terhadap seseorang yang dilakukan dengan paksaan, oleh siapapun

${ }_{18}$ United Nations High Commissioner for Refugees, 2003

19 Ridhana Swantika Chresna, 'Implementasi Convention on Then Elimination of All Forms Discrimination Against Women (CEDAW) Terhadap Kasus Kekerasan Seksual', Skripsi Fakultas Ilmu Sosial dan Ilmu Politik Universitas Airlangga, (2011).[14]

${ }^{20}$ Article 1 Understanding and Addressing Violence against Women of World Health Organization. 
tanpa memandang hubungan dengan korban, yang dalam pengaturannya berbentuk apapun akan termasuk dalam kekerasan seksual, maka hal ini tidak terbatas pada lingkungan rumah maupun pekerjaan. Pemaksaan yang dimaksud dapat mencakup berbagai tingkat kekuatan, intimidasi psikologis, pemerasan, maupun ancaman (baik yang dalam hal ancaman untuk menyakiti fisik maupun untuk tidak mendapatkan posisi pekerjaan yang diinginkan).

\section{Pengaturan Kekerasan seksual dalam Hukum Internasional}

CEDAW mengecam tindakan atas kekerasan seksual pada perempuan dengan dilakukannya pengadopsian resolusi 1820 tahun 2008 oleh Dewan Keamanan PBB dalam rangka memelihara perdamaian dan keamanan internasional. Demikian PBB secara tegas menanggapi bahwa kekerasan seksual sebagai sebuah kejahatan internasional.

\section{Kekerasan Seksual sebagai Kejahatan Kemanusiaan.}

Berdasarkan Pasal 7 Ayat 1 huruf (g) Rome Statute of the International Criminal Court yang berbunyi :

"For the purpose of this Statute, "crime against humanity" means any of the following acts when committed as part of a widespread or systematic attack directed against any civilian population, with knowledge of the attack : ... (g) Rape, sexual slavery, enforced prostitution, forced pregnancy, enforced sterilization, or any other form of sexual violence of comparable gravity;... , ${ }^{21}$

Berdasarkan pasal tersebut kekerasan seksual dapat dikategorikan dalam tindak kejahatan terhadap kemanusiaan. Namun terdapat unsur-unsur yang harus terpenuhi yakni:22

1. Pelaku melakukan tindakan kekerasan seksual terhadap seserang atau lebih atau menyebabkan orang yang bersangkutan atau orang-orang untuk terlibat dalam tindakan seksual dengan kekerasan.

2. Pelaku melakukan tindak kekerasan seksual tersebut dengan ancaman

${ }^{21}$ Pasal. 7 Ayat 1 huruf g Rome Statute of the International Criminal Court, 1974.

${ }^{22}$ Theodor Meron, 'Rape as a Crime Under International Humanitarian Law', (87 Am. J. Int'1, 1993).[424 - 427]. 
kekerasan atau pemaksaan, seperti memberikan rasa takut akan kekerasan, paksaan, penahanan, penekanan psikologis atau penggunaan kekuasaan, terhadap seseorang atau orang lain, atau dengan mengambil kesempatan dari lingkungan yang memaksa atau ketidakmampuan seseorang atau yang bersangkutan untuk memberikan persetujuan dengan ikhlas.

3. Kekerasan tersebut dilakukan sebagai bagian dari serangan yang meluas dan sistematis yang ditujukan kepada kelompok penduduk sipil.

Berdasarkan unsur-unsur di atas, maka pelaku dari tindak kekerasan seksual yang dimaksud dapat seorang kombatan yang yang merupakan pihak dari konflik yang terjadi. Statuta dan sumber hukum lain mendefinisikan cakupan dari kejahatan ini dengan berbeda-beda, namun pada dasarnya kejahatan terhadap kemanusiaan terdiri atas tindakan yang tidak manusiawi (seperti pembunuhan, penyiksaan, kekerasan seksual) yang dilakukan sebagai bagian dari dari serangan yang sistematis atau meluas yang ditujukan kepada populasi penduduk sipil. ${ }^{23}$

Pada awalnya Statuta ICTY mensyaratkan adanya hubungan terhadap konflik bersenjata, statuta membuat elemen tersebut sebagai persyaratan yurisdiksional, sehingga bukti dari konflik bersenjata merupakan elemen pilihan terhadap kejahatan di pengadilan lain. Dewan Banding ICTY pun telah menegaskan bahwa berdasarkan hukum kebiasaan internasional, dan seperti yang telah diterapkan oleh Pengadilan, persyaratan umum untuk kejahatan kemanusiaan yakni: “(i) harus ada serangan; (ii) tindakan pelaku harus menjadi bagian dari serangan; (iii) serangan harus ditujukan kepada populasi penduduk sipil; dan (iv) serangan harus bersifat sistematis atau meluas".

Syarat umum di atas untuk dapat dikatakan sebagai kejahatan kemanusiaan yakni "sistematis" berarti memerlukan adanya sebuah rencana atau kebijakan. Namun ternyata oleh Dewan Banding ICTY belakangan ini dinyatakan bahwa tidak harus demikian. Dimana sebuah rencana ataupun kebijakan mungkin

${ }^{23}$ Matthew Lippman, 'The 1948 Convention on the Prevention and Punishment of the Crime of Genocide: FortyFive Years Later', (Int'l \& Comp. L.J., 1994). [344-348]. 
bersifat indikatif dari sifat sistematis kejahatan sehingga akan menjadi "bukti yang relevan", tetapi hal tersebut bukan merupakan elemen legal dari kejahatan tersebut. Hal ini berarti dimungkinkan sebuah tindakan kekerasan seksual akan tetap dikategorikan dalam kejahatan kemanusiaan berdasarkan statuta tersebut sekalipun syarat sistematis atau meluasnya tidak terpenuhi dan pelaku merupakan bukan kombatan dari perang yang terjadi.

\section{Kekerasan Seksual sebagai Penyiksaan.}

Pasal 7 Ayat 1 huruf (f) dalam Rome Statute of the International Criminal Court mengatakan bahwa penyiksaan yang dikategorikan berat dalam aturan tersebut adalah masuk dalam kejahatan terhadap kemanusiaan. Sebagaimana tertulis dalam statuta tersebut :

"For the purpose of this Statute, "crime against humanity" means any of the following acts when committed as part of a widespread or systematic attack directed against any civilian population, with knowledge of the attack : ... (f) Torture; ...."

Selanjutnya dalam Pasal 2 huruf (f) dari Rome Statute menjelaskan Penyiksaan yang dimaksud dari pasal 1 sebelumnya, sebagaimana berbunyi :

“(e) 'Torture' means the intentional infliction of severe pain or suffering, whether physical or mental, upon a person in the custody or under the control of the accused; except that torture shall not include pain or suffering arising only from, inherent in or incidental to, lawful sanctions; ... ".

Dimana Penyiksaan tersebut adalah Timbulnya secara sengaja sakit atau penderitaan yang hebat, baik fisik maupun mental terhadap seseorang yang ditahan atau dibawah oleh penguasaan oleh tertuduh.

Menurut Konvensi Menentang Penyiksaan dan Perlakuan atau Hukuman Lain yang Kejam, Tidak Manusiawi atau Merendahkan (Konvensi Menentang Penyiksaan) tahun 1984 Penyiksaan adalah :

"For the purposes of this Convention, the term "torture" means any act by which severe pain or suffering, whether physical or mental, is intentionally inflicted on a person for such purposes as obtaining from him or a third person information or a confession, punishing him for an act he or a third person has committed or is suspected of having committed, or intimidating or coercing him or a third person, or for any reason based on discrimination of any kind, when such pain or suffering is inflicted by or at the instigation of or 
with the consent or acquiescence of a public official or other person acting in an official capacity. It does not include pain or suffering arising only from, inherent in or incidental to lawful sanctions."

Berdasarkan konvensi tersebut, definisi dari penyiksaan ialah :

1. Melibatkan penderitaan yang parah;

2. Dilakukan secara sengaja untuk suatu tujuan (yaitu bukan karena kecelakaan), seperti: mendapatkan informasi atau pengakuan, menghukum, mengintimidasi, memaksa, dengan berbagai alasan atas dasar diskriminasi dalam bentuk apa pun;

3. Dilakukan oleh seorang pejabat publik atau orang lain yang berperan dalam kapasitas resmi, atau atas dorongannya atau dengan izin atau persetujuannya.

Dalam hukum internasional kekerasan seksual dapat mencakup berbagai tindak kejahatan seperti: pemerkosaan; perbudakan seksual; pelacuran paksa; penghamilan paksa; dan sterilisasi paksa. Kekerasan seksual tersebut dapat menjadi tuntutan penyiksaan sebagaimana Dewan Pengadilan menekankan bahwa "untuk memasukkan pemerkosaan di dalam tuntutan penyiksaan, pemerkosaan harus memil iki beberapa elemen dari pelanggaran tersebut". ${ }^{24}$

Dewan pengadilan merumuskan Elemen dari penyiksaan untuk tujuan ketetapan kejahatan perang dari Statuta ICTY, yakni : (i) harus ada tindakan atau kelalaian yang menyebabkan rasa sakit atau penderitaan yang hebat, baik itu fisik maupun mental, (ii) dilakukan secara sengaja, (iii) dengan tujuan untuk mengambil informasi atau mendapatkan pengakuan dari korban, atau orang ketiga, menghukum korban atas tindakan yang ia atau orang ketiga telah lakukan atau diduga telah dilakukan, mengintimidasi dan memaksa korban atau pihak ketiga, atau dengan alasan apapun mendasarkan pada diskriminasi, (iv) dan tindakan atau kelalaian tersebut telah dilakukan, atau dihasut, atau dengan kesadaran dari pihak yang berwenang atau orang lain yang bertindak di dalam kapasitas wewenangnya. ${ }^{25}$ Berdasarkan pertimbangan yang dilakukan oleh Dewan Pengadilan terkait

${ }^{24}$ Komnas Perempuan, Buku Referensi Hukum Pidana Internasional dan Perempuan (Raol Wallenberg Institute 2017).[145].

25 ibid.[146] 
pemerkosaan, tindak kekerasan seksual ini dapat dikategorikan sebagai tindakan yang dapat menyerang inti dari martabat manusia dan integritas fisik mereka. Maka hukuman dari pemerkosaan menjadi semakin penting ketika hal tersebut dilakukan oleh, atau dengan hasutan dari pejabat publik, atau dengan kesadaran dari pejabat yang berwenang. Pemerkosaan menyebabkan penderitaan yang hebat, baik secara fisik maupun psikologis. Penderitaan psikologis dari seseorang yang telah diperkosa terjadi mungkin karena kondisi budaya dan sosial dan dapat berdampak berkepanjangan. Bahkan, sulit sekali menggambarkan keadaan di mana pemerkosaan, oleh, atau atas hasutan dari pejabat publik, atau dengan kesadaran dari pejabat yang berwenang, dapat dipertimbangkan sebagai sesuatu yang memiliki tujuan, yang tidak melibatkan hukuman, pemaksaan, diskriminasi maupun intimidasi. Melalui pandangan Dewan Pengadilan hal ini secara alami sudah terdapat di dalam situasi konflik bersenjata. ${ }^{26}$

Sebagaimana tuntutan dalam kasus Delic dalam Pengadilan Yugoslavia pada tahun 1998. Ia dituntut dengan penyiksaan sesuai dengan Pasal 2 sebagai pelanggaran keji dari The Geneva Convention tahun 1949 dan Pasal 3 sebagai pelanggaran hukum atau kebiasaan perang. Dewan Pengadilan menekankan bahwa Delic menggunakan kekerasan seksual yang menyebabkan penderitaan dalam rangka mendapatkan informasi dan mengintimidasi korbannya agar mau bekerjasama dengannya. Tindakan yang menyebabkan penderitaan hebat dan luka serius atau kesehatan secara terencana merupakan pelangaran keji dari Konvensi Jenewa, dimana dinyatakan bahwa tindakan tersebut terdiri dari tindakan atau kelalaian yang disengaja sehingga mengakibatkan penderitaan atau luka mental maupun fisik yang serius, sehingga aspek penyiksaan masuk dalam tindak kejahatan yang terjadi.

Penjelasan terkait definisi Tindakan kekerasan seksual sebagai penyiksaan berdasarkan beberapa konvensi dan pertimbangan Dewan Pengadilan menekankan bahwa sebuah tindak kekerasan seksual dapat di kategorikan sebagai penyiksaan bila tindakan tersebut sengaja dilakukan oleh pejabat publik atau seseorang yang

${ }^{26}$ ibid. $[148]$ 
dalam kapasitas resmi dan mendapatkan persetujuan dari pihak berwenang dengan tujuan mendapatkan sesuatu dari korban seperti informasi, sehingga dilakukan dan mengakibatkan penderitaan yang parah.

\section{Kekerasan Seksual Oleh Pejabat Publik dalam Perang}

Di tengah masyarakat internasional, kasus kekerasan seksual sudah sering terjadi. Berdasarkan resolusi 1820 tahun 2008 kekerasan seksual adalah salah satu tactic of war, hal ini sangatlah efektif dikarenakan selain tidak membutuhkan biaya yang sangat besar juga tidak memerlukan sistem persenjataan dalam menaklukan populasi manusia, Demikian kekerasan seksual merupakan suatu kejahatan kemanusiaan dan kejahatan perang yang dapat mengancam keberadaan umat manusia.

Salah satu dari kasus kekerasan seksual dalam masyarakat internasional adalah Kasus Akayesu. Dalam kasus ini, Jean Paul Akayesu sebagai walikota komunitas Taba didakwa melakukan genosida, kejahatan kemanusiaan dan kejahatan perang. Dalam hal ini, Akayesu mengetahui terjadinya kekerasan seksual namun membiarkannya terjadi di beberapa tempat yang ada di lingkungan komunitas Taba. Putusan pengadilan atas Akayesu menyatakan dengan jelas bahwa kekerasan seksual yang terjadi di komunitas Taba dan seluruh Rwanda merupakan tindakan genosida. Dalam kasus Akayesu dinyatakan bahwa kekerasan seksual yang termasuk perkosaan di dalamnya, adalah setiap perbuatan bersifat seksual yang dilakukan terhadap seseorang yang berada di bawah tekanan. Kekerasan seksual tidak terbatas pada serangan fisik, namun juga dapat mencakup perbuatan yang tidak mengandung penetrasi atau bahkan kontak fisik. Perkosaan dan kekerasan seksual merupakan genosida seperti juga tindak kejahatan lainnya sepanjang tindakan tersebut dimaksudkan untuk menghancurkan, baik secara keseluruhan maupun sebagian, kelompok tertentu, yang dijadikan sasaran. ${ }^{27}$ Atas Putusan tersebut, Pengadilan Akayesu memberikan kontribusi penting terhadap perkembangan hukum dalam hukum internasional untuk kasus perkosaan sebagai suatu kejahatan perang dengan

${ }^{27}$ Veriena J.B. Rehatta, 'Kekerasan Seksual Terhadap Perempuan' (2014) 20 Jurnal Sasi.[57]. 
menyatakan perkosaan sebagai suatu kejahatan terhadap kemanusiaan. ${ }^{28}$

Contoh kasus kekerasan seksual lain yang terjadi di tengah masyarakat internasional adalah Kasus Furundzija. Anto Furundzija adalah komandan lokal pada unit khusus polisi militer HVO di Vitez. Ia dinyatakan bersalah pada 10 Desember 1998 atas penyiksaan dan perkosaan terhadap perempuan Muslim Bosnia selama berlangsungnya interogasi serta membantu dan bersekongkol dalam tindak kejahatan perkosaan. ${ }^{29}$ Kekerasan seksual di bekas negara Yugoslavia dilakukan dengan cara memberikan persetujuan diam-diam dan/atau memberikan dukungan sebagai pihak yang berpotensi melakukan penyiksaan. ${ }^{30}$ Salah satu keputusannya menegaskan bahwa terdakwa bersalah telah melakukan pemerkosaan dan kejahatan terhadap kemanusiaan. Putusan pengadilan dalam Kasus Furundzija menegaskan bahwa kekerasan seksual menurut aturan hukum pidana internasional tidak hanya perkosaan saja, tetapi juga meliputi setiap serangan seksual yang serius yang tidak cukup dengan adanya penetrasi aktual saja. Perbuatan ini mencakup semua serangan yang sifatnya seksual yang dilakukan terhadap integritas fisik dan moral seseorang dengan cara-cara yang mengandung paksaan, ancaman kekerasan atau intimidasi sehingga merendahkan dan menghina martabat korban. ${ }^{31}$

Merujuk pada kasus-kasus dan putusan pengadilan internasional yang telah ada terkait dengan kekerasan seksual, dapat disimpulkan bahwa kekerasan seksual merupakan suatu kejahatan yang dapat dikategorikan dalam The most serious crime sebagaimana dimaksud pada Statuta Roma pada Pasal 7 Ayat 1 huruf (f) dan (g) yang mengatur tentang Kejahatan Terhadap Kemanusiaan dimana kekerasan seksual masuk dalam unsur-unsurnya. Kekerasan seksual memiliki arti yang lebih luas karena bukan hanya perkosaan saja. Oleh karena itu Statuta Roma mencantumkan "bentuk lain dari kekerasan seksual yang kekejiannya setara” sebagaimana yang ada dalam Pasal 7 Ayat 1 Huruf (g) Statuta Roma. Hal ini dimaksudkan untuk

\footnotetext{
28 ibid.[58].

29 ibid.[59].

${ }^{30}$ ibid.

31 ibid, [61].
} 
menjangkau setiap tindak kekerasan yang dilakukan untuk maksud-maksud seksual atau dengan sasaran seksualitas.

Kekerasan seksual yakni perkosaan dan bentuk-bentuk lain dari kekerasan seksual tercakup dalam most serious crime terhadap hukum yang berlaku pada konflik bersenjata internasional sebagaimana diatur dalam Statuta Roma dalam konteks kejahatan perang (war crime) yang dapat pula dimasukkan sebagai pelanggaran berat terhadap The Geneva Convention 1949.

\section{Kekerasan Seksual Oleh Personil Organisasi Internasional di Suriah}

Berdasarkan laporan dari Shan Women's Action Network di tahun 2002, CEDAW menggaris bawahi bahwa dari tahun ke tahun kasus kekerasan seksual semakin meningkat sejak tahun $1996 .{ }^{32}$ Tindakan kekerasan seksual tidak hanya terjadi saat konflik, melainkan juga saat proses melarikan diri dari konflik dan di tenda pengungsi, situasi dimana struktur sosial mengalami disintegrasi. ${ }^{33}$

Berbeda dengan Kasus Akayesu dan Kasus Furundzija yang telah diselesaikan dengan Putusan Pengadilan, dan berfokus pada war crime sehingga kebanyakan pelakunya adalah kombatan, pada tahun 2015 terjadi kasus kekerasan seksual di Suriah. Konflik Suriah sebenarnya telah berlangsung sejak tahun 2011 yang dipicu oleh Arab Spring. Konflik yang berkepanjangan ini memaksa warga Suriah untuk melarikan diri dari rumah dalam rangka berlindung. Berdasarkan data dari UNHCR, pada Februari 2017 sebanyak 3,2 juta pengungsi Suriah melarikan diri dari rumah mereka dan mengungsi ke pengungsian dalam negeri maupun luar negeri. Para warga mencari perlindungan baik di dalam negeri dengan mendatangi tenda-tenda pengungsi yang ada maupun ke negara lain terutama negara tetangga

${ }^{32}$ Shan Women's Action Network, 'Stop License to rape in Burma for the 59th Session', (The UN Commission on Human Rights, 2003) < http://www.apwld.org/pdf/SWANCHR-paper.pdf > accessed 18 Maret 2019.

33 Hynes dan Cardozo, 'Peran United Nations High Commissioner for Refugees dalam Menangani Pengungsi Suriah Korban Sexual and Gender-Based Violence di Lebanon'(Repository Undip, 2000). 
seperti Turki dan Lebanon. ${ }^{34}$

Salah satu lokasi pengungsian di dalam negeri adalah di wilayah bagian selatan Suriah yakni di Dara'a dan Quneitra. Berdasarkan hasil survei yang dilakukan oleh The International Rescue Committee terhadap 190 perempuan dan anak perempuan di wilayah tersebut, ditemukan bahwa $40 \%$ dari mereka telah mengalami kekerasan seksual. ${ }^{35}$

Dalam kasus ini, Berdasarkan 15 Bentuk Kekerasan Seksual, Komisi Nasional Anti Kekerasan terhadap Perempuan menyatakan kekerasan seksual yang terjadi di Suriah adalah tindak kekerasan seksual dengan penyalahgunaan kekuasaan, atau penyalahgunaan kepercayaan, untuk tujuan kepuasan seksual, maupun untuk memperoleh keuntungan dalam bentuk uang, sosial, politik dan lain sebagainya. Perempuan dan anak yang menerima tindakan kekerasan seksual dari para pemberi bantuan dalam rangka mendapatkan makanan dan minuman untuk keluarganya. Para pemberi bantuan tersebut memaksa perempuan atau anak perempuan yang datang pada mereka dengan kekuasaannya sebagai penyalur bantuan untuk melayani keinginan seksual mereka sebelum para perempuan dan anak perempuan menerima bantuan yang disediakan oleh Organisasi Internasional penyedia bantuan kemanusiaan. Kekerasan seksual yang dilakukan sebagaimana dijelaskan di atas dapat dikatakan sebagai kekerasan seksual dalam bentuk eksploitasi seksual. ${ }^{36}$ Beberapa anak perempuan yang menolak akan didatangi oleh para pemberi bantuan dan memaksa orangtua dari si anak untuk meminta anaknya melayani mereka dengan berbagai ancaman. ${ }^{37}$ Pemberi bantuan tersebut merupakan perwakilan dari organisasi internasional yang diberikan tugas dan wewenang untuk menyalurkan bantuan kemanusiaan.

${ }^{34}$ Adinda Ayu Shabrina, 'Peran United Nations High Commissioner for Refugee dalam Menangani Pengungsi Suriah Korban Sexual and Gender-based Violence di Lebanon' (2018) 4 Journal of Internaional Relations.[81-89].

${ }^{35}$ Konflik Suriah, 'Perempuan dieksploitasi secara seksual dengan imbalan bantuan kema-

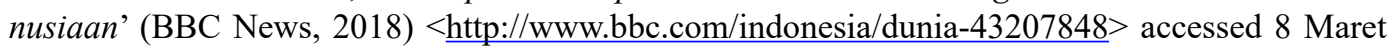
2019.

\footnotetext{
${ }^{36}$ ibid.

${ }^{37}$ Op. Cit.
} 
Survei dari International Rescue Committee menyatakan bahwa para pemberi bantuan tersebut merupakan perwakilan dari organisasi internasional di bawah PBB. Berbeda dengan kasus-kasus yang sebelumnya, dalam kasus kekerasan seksual yang terjadi di Suriah, kekerasan seksual dilakukan oleh personil organisasi internasional, sehingga perlu diketahui tanggungjawab atas kekerasan seksual tersebut melekat pada organisasi yang membawahi pemberi bantuan atau melekat pada individu.

\section{Kesimpulan}

Definisi kekerasan seksual dalam hukum internasional berkembang mengikuti kondisi saat terjadinya tindakan kekerasan seksual tersebut, dimana tindakan kekerasan seksual tersebut terjadi dalam kondisi konflik bersenjata atau dalam kondisi tanpa konflik bersenjata yakni dalam kehidupan rumah tangga maupun pekerjaan. Kekerasan seksual dalam Hukum Internasional diatur dalam beberapa pengaturan diantaranya dalam Rome Statute of the International Criminal Court Tahun 1974 yang mengkategorikan kekerasan seksual sebagai the most serious crimes. Selanjutnya diatur pula dalam Convention on Then Elimination of All Forms Discrimination Against Women dimana pengaturannya lebih kepada tindakan preventif terkait perlindungan dari kekerasan seksual, dari Konvensi ini pula muncul pengklasifikasian kekerasan seksual oleh Komnas Perempuan. Ke-15 bentuk kekerasan seksual tersebut yakni: Perkosaan; Intimidasi Seksual termasuk ancaman atau percobaan perkosaan; Pelecehan Seksual; Eksploitasi Seksual; Perdagangan Perempuan untuk Tujuan Seksual; Prostitusi Paksa; Perbudakan Seksual; Pemaksaan Perkawinan; Pemaksaan Kehamilan; Pemaksaan Aborsi; Pemaksaan Kontrasepsi dan Sterilisasi; Penyiksaan Seksual; Penghukuman tidak manusiawi danbernuansa seksual; Praktik tradisi bernuansa seksual yang membahayakan atau mendiskriminasi perempuan; dan Kontrol seksual, termasuk lewat aturan diskriminatif beralasan moralitas dan agama.

Berdasarkan pengaturan tersebut, perlindungan yang diberikan oleh Hukum Internasional sejauh ini lebih banyak mencakup hal-hal preventif dari pada represif 
sehingga dalam hal represif masih perlu pengaturan yang lebih spesifik mengenai akibat hukum yang dapat diberikan kepada pelaku kekerasan seksual tersebut.

\section{Daftar Bacaan}

\section{Buku}

Peter Mahmud Marzuki, Penelitian Hukum (Kencana Prenada Media Group 2008).

Komnas Perempuan, 'Buku Referensi Hukum Pidana Internasional dan Perempuan',(Raol Wallenberg Institute, 2017).

Atikah Nuraini et al, 'Hukum Pidana Internasional dan Perempuan : Sebuah Resource Book untuk Praktisi’, (Komnas Perempuan, 2013).

\section{Jurnal}

Adinda Ayu Shabrina, 'Peran United Nations High Commissioner for Refugee (UNHCR) dalam Menangani Pengungsi Suriah Korban Sexual and Gender - based Violence (SGBV) di Lebanon' (2018) 4 Journal of International Relations.

Veriena J.B. Rehatta, 'Kekerasan Seksual Terhadap Perempuan' (2014) 20 Jurnal Sasi.

\section{Skripsi}

Sevirna Ratri Aryani, 'Astana Process sebagai Mekanisme Penyelesaian Konflik di Suriah', Skripsi Fakultas Hukum Universitas Airlangga, (2018).

Ridhana Swastika Chresna, 'Implementasi Convention on The Elimination of All Forms Discrimination Against Women (CEDAW) terhadap Kasus Kekerasan Seksual di Wilayah Shan Myanmar pada 1996-2001', Skripsi Fakultas Ilmu Sosial dan Ilmu Politik Universitas Airlangga, (2012).

\section{Laman}

Abuja, 'Nigeria : Boko Haram Attacks Cause Humanitarian Crisis' (Human Rights Watch, 2014) <http://www.hrw.org/news/2014/03/14/nigeria-boko-haramattacks-cause-humanitarian-crisis $>$, accessed 22 November 2018.

Bernat Armangue, '75 \% Anak di Dunia Jadi Korban Kekerasan' (VOA, 2017) $<$ https://www.voaindonesia.com/a/tujuh-puluh-lima-persen-anak-di-duniajadi-korban-kekerasan/4047830.html>, accessed 28 September 2018. 
Laila Bassam, 'Iran troops to join organisasi internasional Syria war, Russia bombs group trained by CIA', (World News, 2015) < $\underline{\text { http://www.reuters. }}$ com/article/us-mideast-crisis-russia-syria/iran-trooPasal-to-join-syria-warrussia-bombs-group-trained-by-cia-idUSKCN0RV41O20151002> accessed 27 November 2018.

Fawaz Gerges, 'Saudi Arabia and Iran must end their proxy in Syria', (The Guardian.com, 2013) <http://www.theguardian.com/commentisfree/2013/ dec/15/saudia-arabia-iran-proxy-war-syria $>$, accessed 27 November 2018.

Crime Burma, 'Analysis of Sexual Violence', (International Human Rights in Clinic Harvard Law School, 2009) < $\underline{\text { http://www.law.harvard.edu/programs/ }}$ hrp/documents/Crimes-in-Burma.pdf > accessed 27 November 2018.

Konflik Suriah, 'Perempuan dieksploitasi secara seksual dengan imbalan bantuan kemanusiaan' (BBC News, 2018) <http://www.bbc.com/indonesia/ dunia-43207848> accessed 8 Maret 2019.

\section{Instrumen Hukum}

Convention on the Elimination of all Forms of Discrimination Againts Women (CEDAW), Adopted and opened for signature, ratification and accession by General Assembly resolution 34/180 of 18 December 1979 entry into force 3 September 1981.

Rome Statute of the International Criminal Court, adopted by the United Nations Diplomatic Conference of Plenipotentiaries on the Establishment of an International Criminal Court on 17 July 1998.

Report of The United Nations High Commissioner for Refugees, The United Nations General Assembly adopted the statute creating UNHCR on December 14, 1950 . 